\title{
The Italian arm of the PREPARE study: an international project to evaluate and license a maternal vaccine against group $B$ streptococcus
}

Alberto Berardi ${ }^{1 *}$ (D) Tiziana Cassetti ${ }^{2}$, Roberta Creti ${ }^{3}$, Caterina Vocale ${ }^{4}$, Simone Ambretti ${ }^{5}$, Mario Sarti ${ }^{2}$, Fabio Facchinetti ${ }^{6}$, Stephen Cose $^{7,8}$, the Prepare Network, Paul Heath ${ }^{9}$ and Kirsty Le Doare ${ }^{10}$

\begin{abstract}
Background: Group B streptococcus (GBS) is a leading cause of sepsis, pneumonia and meningitis in infants, with long term neurodevelopmental sequelae. GBS may be associated with poor pregnancy outcomes, including spontaneous abortion, stillbirth and preterm birth. Intrapartum antibiotic prophylaxis (IAP) is currently the only way to prevent early-onset disease (presenting at 0 to 6 days of life), although it has no impact on the disease presenting over 6 days of life and its implementation is challenging in resource poor countries. A maternal vaccine against GBS could reduce all GBS manifestations as well as improve pregnancy outcomes, even in low-income countries.

Main body: The term "PREPARE" designates an international project aimed at developing a maternal vaccination platform to test vaccines against neonatal GBS infections by maternal immunization. It is a non-profit, multi-center, interventional and experimental study (promoted by the St George University of London. [UK]) with the aim of developing a maternal vaccination platform, determining pregnancy outcomes, and defining the extent of GBS infections in children and mothers in Africa. PREPARE also aims to estimate the protective serocorrelates against the main GBS serotypes that cause diseases in Europe and Africa and to conduct two trials on candidate GBS vaccines. PREPARE consists of 6 work packages. In four European countries (Italy, UK, Netherlands, France) the recruitment of cases and controls will start in 2020 and will end in 2022. The Italian PREPARE network includes 41 centers. The Italian network aims to collect: GBS isolates from infants with invasive disease, maternal and neonatal sera (cases); cord sera and GBS strains from colonized mothers whose infants do not develop GBS infection (controls).
\end{abstract}

Short conclusion: PREPARE will contribute information on protective serocorrelates against the main GBS serotypes that cause diseases in Europe and Africa. The vaccine that will be tested by the PREPARE study could be an effective strategy to prevent GBS disease.

Keywords: Group B streptococcus, Vaccine, Newborn, Sepsis, Meningitis, Prevention

\footnotetext{
* Correspondence: alberto.berardi@unimore.it

'Unità Operativa di Terapia Intensiva Neonatale, Dipartimento Integrato

Materno-Infantile, Azienda Ospedaliero-Universitaria Policlinico, Via del Pozzo,

71, 41124 Modena, Italy

Full list of author information is available at the end of the article
}

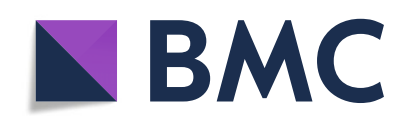

( ) The Author(s). 2020 Open Access This article is licensed under a Creative Commons Attribution 4.0 International License, which permits use, sharing, adaptation, distribution and reproduction in any medium or format, as long as you give appropriate credit to the original author(s) and the source, provide a link to the Creative Commons licence, and indicate if changes were made. The images or other third party material in this article are included in the article's Creative Commons licence, unless indicated otherwise in a credit line to the material. If material is not included in the article's Creative Commons licence and your intended use is not permitted by statutory regulation or exceeds the permitted use, you will need to obtain permission directly from the copyright holder. To view a copy of this licence, visit http://creativecommons.org/licenses/by/4.0/. The Creative Commons Public Domain Dedication waiver (http://creativecommons.org/publicdomain/zero/1.0/) applies to the data made available in this article, unless otherwise stated in a credit line to the data. 


\section{Background}

Group B streptococcus (GBS or Streptococcus agalactiae) is a Gram-positive pathogen belonging to Lancefield group B. It is a common commensal of the gastrointestinal tract and colonizes $10-30 \%$ of pregnant women at vaginal or vaginal/rectal sites [1]. In pregnant women, GBS is a frequent causative agent in urinary tract infections, chorioamnionitis and postpartum endometritis, and it is also associated with poor pregnancy outcomes, including spontaneous abortion, stillbirth and preterm birth [2].

GBS is a leading cause of sepsis, pneumonia and meningitis in infants, with long-term neurodevelopmental sequelae. Neonatal GBS infections are usually divided into Early-Onset Disease (EOD, presenting at 0 to 6 days of life) and Late-Onset Disease (LOD, presenting at 7 to 90 days of life) [3]. EOD is prevented through intrapartum antibiotic prophylaxis (IAP) in women with GBS colonization or obstetrical risk factors for GBS vertical transmission.

\section{Main text}

The term "PREPARE" designates an international project entitled "Prevention of invasive Group B Streptococcus disease in young infants: a pathway for the evaluation \& licensure of an investigational maternal GBS vaccine". PREPARE is aimed at developing a vaccine against neonatal GBS infections and is promoted by the St George University of London (UK) (see https://gbsprepare.org).

This project is part of the EDCTP2 program (European \& Developing Countries Clinical Trials Partnership) that funds research for prevention and treatment of poverty-related infectious diseases in sub-Saharan Africa and it is aligned with the WHO roadmap [1]. Moreover, PREPARE is supported by Horizon 2020 (European Union's Framework Program for Research and Innovation).

Strategies implementing IAP, especially those that screen women in late pregnancy for vagino-rectal GBS colonization (regardless of presenting risk factors) has led to a dramatic decline in the incidence rates of EOD (i.e., from 0.37 to 0.22 per 1000 live births from 2006 to 2017 in USA) [4]. However, IAP coverage is incomplete even in the best of settings. Furthermore, the burden of invasive GBS disease may be high in resource poor countries such as Africa (estimated incidence of 1.12/ 1000 live births) where IAP implementation is challenging [5]. Concerns have arisen as to the possible negative impact of large-scale prevention, as IAP may promote the emergence of antibiotic resistance, and early exposure to antibiotics can disrupt the development of the intestinal microbiome, with consequences in adulthood [6]. Finally, IAP has no impact on LOD, stillbirths and prematurity due to GBS, as well as a limited impact on disease in pregnant women [7]. Further strategies are urgently required to decrease GBS-associated morbidity and mortality.

There are ten known GBS serotypes (Ia, Ib and II-IX), but serotype Ia, III and V are more commonly responsible of invasive GBS disease in infants under 90 days of life. Multivalent vaccines administered to pregnant women to protect their infants against GBS disease could overcome many of the outstanding issues related to IAP and could be an effective strategy for resourcepoor countries. Indeed, compared to WHO European region, in WHO African region mortality rates are 7 times higher (7/1000 vs 51/1000 LBs) [8].

Therefore, the prevention of neonatal infections through maternal immunoprophylaxis is a topic that has recently aroused wide attention. The purpose of this strategy is to induce maternal protective immunity resulting in a specific transplacental IgG passage. Indeed, recent data have shown that vaccinating pregnant women does not increase adverse events or fetal risks [9]. WHO data from developing countries show a $92 \%$ decline (from the 1980s to 2000) in neonatal tetanus case fatalities following maternal vaccination with tetanus toxoid [10].

It is estimated that to detect a $75 \%$ reduction in EOD and LOD in countries with a disease incidence of more than $1 / 1000$ births it would be necessary to enroll about 60,000 pregnant women to study the effectiveness of the vaccine, assuming that this protects from $90 \%$ of circulating serotypes [11]. Therefore, in order to facilitate the licensure of a vaccine, the study of protective serocorrelates, followed by a demonstration of a post-license efficacy, aroused interest. Although previous studies have shown an association between serotype-specific maternal IgG titers and reduction of neonatal disease risk, no study has been able to establish with certainty a protective antibody threshold value, due to different assays for determining antibody titers or inability to compare and pool the results of different studies [12]. Vaccines have been tested against serotype-specific capsular polysaccharide and against surface proteins that are expressed in different serotypes and could then protect against specific serotypes $[7,12]$.

PREPARE is a non-profit, multi-center, interventional and experimental study. It aims to develop a maternal vaccine platform in Uganda, determine pregnancy outcomes and to define the extent of GBS infections in children and mothers in a sub-Saharan context. It also aims to estimate the protective serocorrelates against the main GBS serotypes that cause diseases in Europe and Africa and to conduct two trials on candidate GBS vaccines. The PREPARE project involves 7 countries across the world (Malawi, Uganda, South Africa, the United Kingdom, the Netherlands, Italy and France) and aims to develop a serum biobank, in order to define 
Table 1 Work-Packages (WP) of the PREPARE Study: role, goals and participating countries

\begin{tabular}{|c|c|c|c|}
\hline $\begin{array}{l}\text { Work } \\
\text { packages }\end{array}$ & Role in the project & Goals & $\begin{array}{l}\text { Participating } \\
\text { country }\end{array}$ \\
\hline WP1 & $\begin{array}{l}\text { Project Management, Scientific } \\
\text { Coordination and Oversight of Capacity } \\
\text { Building. }\end{array}$ & $\begin{array}{l}\text { To ensure conduct of all research activities to the highest standards, } \\
\text { including oversight and coordination of the other WPs to ensure deliverables } \\
\text { and milestones are met. }\end{array}$ & $\begin{array}{l}\text { United } \\
\text { Kingdom } \\
\text { South Africa }\end{array}$ \\
\hline WP2 & $\begin{array}{l}\text { Clinical trial site development and GBS } \\
\text { disease surveillance. }\end{array}$ & $\begin{array}{l}\text { To establish the GBS disease incidence in an urban Ugandan cohort followed } \\
\text { to } 3 \text { months of age and establish the baseline rates of common obstetric and } \\
\text { neonatal outcomes in preparation for WP4 and WP5. }\end{array}$ & $\begin{array}{l}\text { Uganda } \\
\text { South Africa } \\
\text { United } \\
\text { Kingdom }\end{array}$ \\
\hline WP3 & $\begin{array}{l}\text { Developing serocorrelates of protection } \\
\text { against GBS }\end{array}$ & $\begin{array}{l}\text { To develop a biobank of prospectively collected sera from cases of GBS } \\
\text { disease and associated GBS disease isolates from a network of African and } \\
\text { European sites in order to define serocorrelates of protection against GBS, } \\
\text { using standardized antibody assays. }\end{array}$ & $\begin{array}{l}\text { Uganda, } \\
\text { Malawi, } \\
\text { South Africa, } \\
\text { United } \\
\text { Kingdom, } \\
\text { Italy, } \\
\text { France, } \\
\text { Netherlands }\end{array}$ \\
\hline WP4 & Multivalent CPS-conjugate vaccine trial. & $\begin{array}{l}\text { To conduct a phase II study of a multivalent vaccine against the GBS CPS in } \\
\text { pregnant HIV-infected and uninfected women and to establish a platform for } \\
\text { future trials with new GBS vaccines. }\end{array}$ & $\begin{array}{l}\text { United } \\
\text { Kingdom } \\
\text { Uganda }\end{array}$ \\
\hline WP5 & Minervax Alp-NN GBS vaccine trial. & $\begin{array}{l}\text { To conduct a phase II study of a multivalent vaccine against the Alp and Rib } \\
\text { proteins on the surface of GBS in pregnant HIV-infected and uninfected } \\
\text { women and to establish a platform for future trials with new GBS vaccines. }\end{array}$ & $\begin{array}{l}\text { Denmark } \\
\text { United } \\
\text { Kingdom } \\
\text { South Africa }\end{array}$ \\
\hline WP6 & $\begin{array}{l}\text { Communications, networking and } \\
\text { dissemination. }\end{array}$ & $\begin{array}{l}\text { To develop a strategy for patient and public involvement, communications, } \\
\text { capacity strengthening and stakeholder engagement. }\end{array}$ & $\begin{array}{l}\text { United } \\
\text { Kingdom }\end{array}$ \\
\hline
\end{tabular}

CPS Capsular polysaccharide, GBS group B streptococcus

serocorrelates of protection against GBS, by using standardized antibody assays and a bacterial strains bank to study the characteristics of neonatal and maternal strains.

The overarching objectives will be achieved through 6 work packages (WPs), each with specific aims (Table 1). Italy (that belongs to WP3) is represented by a network made up of 41 centers across the country (Table 2), coordinated by the Azienda Ospedaliero-Universitaria Policlinico (Modena). The Italian network will collect at least 50 neonatal GBS invasive cases (defined as an infant with isolation of GBS from blood culture or from culture of cerebro-spinal fluid) within 2 years. Strains will be sent to the national referring center (Istituto Superiore di Sanità) for GBS typing.

The PREPARE Italian network will collect: i) isolates from infants with invasive disease (cases), together with maternal and neonatal sera collected at the time of diagnosis of infant disease; ii) cord sera and GBS strains (of the same serotype as cases) from colonized mothers whose infants do not develop GBS infection (controls). Biological materials will be used for i) determining the concentration of specific IgG anti-GBS (serotype III the most frequent cause of neonatal disease) in the cord

Table 2 Partner of the PREPARE Consortium

\begin{tabular}{|c|c|c|c|}
\hline Organisation & Country & Role & $\begin{array}{l}\mathrm{H} 2020 \\
\text { type of organisation }\end{array}$ \\
\hline St George's Hospital Medical School (SGUL) & United Kingdom & Coordinator & Secondary or higher education establishment \\
\hline Makerere University - Johns Hopkins University Care Ltd & Uganda & Participant & Research organisation \\
\hline University of Liverpool & United Kingdom & Participant & Secondary or higher education establishment \\
\hline Wits Health Consortium (PTY) LTD & South Africa & Participant & Secondary or higher education establishment \\
\hline Assistance Publique Hopitaux de Paris (AP- HP) & France & Participant & Secondary or higher education establishment \\
\hline Academisch Medisch Centrum bij de Universiteit van Amsterdam & The Netherlands & Participant & Secondary or higher education establishment \\
\hline Azienda Ospedaliero- Universitaria di Modena & Italy & Participant & Secondary or higher education establishment \\
\hline University College London (UCL) & United Kingdom & Participant & Secondary or higher education establishment \\
\hline London School of Hygiene and Tropical Medicine (LSHTM) & United Kingdom & Participant & Secondary or higher education establishment \\
\hline Minervax ApS & Denmark & Participant & Small or medium sized entreprise \\
\hline Pfizer Inc. & United Kingdom & Participant & International Organisation \\
\hline
\end{tabular}


serum of healthy controls and in the serum of infants (aged 0 to 90 days of life) with GBS infection ii) assessing a correlation between antibody concentration and GBS disease risk and iii) validating estimates of protective serocorrelates.

\section{Conclusions}

Despite the progress made in high-income countries in the prevention of EOD, GBS remains an important cause of morbidity and mortality in the first months of life worldwide.

A maternal GBS vaccine could reduce the burden of both EOD and LOD, maternal puerperal sepsis, stillbirth and preterm delivery. A vaccine could help to overcome the inherent limitations of IAP, and could reduce unnecessary antibiotics, as well as costs and long-term disabilities consequent to GBS infection. Finally, a vaccine could be an effective strategy for resource-poor countries, where the antenatal screening and large-scale IAP might be unfeasible. PREPARE aims to undertake clinical trials of a maternal GBS vaccine, to determine pregnancy outcomes, and to estimate the protection serocorrelates against the main GBS serotypes that cause diseases in Europe and Africa.

\section{Acknowledgments}

The Prepare Network:

Non -Italian Contributors

Dr. Merijn van Bijlsma- Academisch Medisch Centrum Bij De Universiteit Van Amsterdam

Prof. Diederik van De Beek- Academisch Medisch Centrum Bij De Universiteit Van Amsterdam

Prof. Claire Poyart- Assistance Publique-Hôpitaux De Paris

Prof. Neil French- The University of Liverpool

Dr. Maryke Nielsen -The University of Liverpool

Prof. Philippa Musoke- Mu-Jhu Care Ltd

Dr Kirsty Le Doare - St George's University of London

Prof. Paul Heath - St George's University of London

Dr Hannah Davies- St George's University of London

Italian Contributors

Dr. Sara Ovale- UO Ostetricia e Ginecologia, Azienda Ospedaliera-

Universitaria, Policlinico di Modena

Dr. Licia Lugli- UO Terapia Intensiva Neonatale, Azienda Ospedaliera-

Universitaria, Policlinico di Modena

Dr. Maria Grazia Capretti- UO Neonatologia, Ospedale Sant'Orsola-Malpighi, Bologna

Prof Marcello Lanari- UO Pediatria d'Urgenza, Ospedale Sant'Orsola-Malpighi, Bologna

Dr. Arianna Dondi- UO Pediatria d'Urgenza, Ospedale Sant'Orsola-Malpighi,

Bologna

Dr. Matilde Ciccia- UO Terapia Intensiva Neonatale, Ospedale Maggiore,

Bologna

Dr. Rosa Francavilla- UO di Pediatria, Ospedale Maggiore, Bologna

Dr. Angela Lanzoni- UO Pediatria, Ospedale S Maria della Scaletta, Imola

Dr. Lorenza Baroni- UO Terapia Intensiva Neonatale, IRCCS, Arcispedale Santa

Maria Nuova, Reggio Emilia

Dr. Sara Fornaciari- UO di Pediatria, IRCCS, Arcispedale Santa Maria Nuova, Reggio Emilia

Dr. Edoardo Carretto- Laboratorio di Microbiologia, IRCCS, Arcispedale Santa Maria Nuova, Reggio Emilia

Dr. Cristina Alessandrini- UO Pediatria, Ospedale di Guastalla

Dr. Gambini Lucia- SC Neonatologia, Azienda Ospedaliero- Universitaria, Parma
Prof. Serafina Perrone- SC Neonatologia, Azienda Ospedaliero- Universitaria, Parma

Prof. Adriana Calderaro- Dipartimento di Medicina e Chirurgia, Università di Parma, Parma

Dr. Pierluigi Bacchini- UO Pediatria dell'Ospedale di Vaio, Fidenza

Dr. Chiara Giugno UO Pediatria, Ospedale B. Ramazzini, Carpi

Dr. Claudio Rota- UO Pediatria, Ospedale Civile, Sassuolo

Dr. Rossella Pagano- UO Pediatria, Ospedale Civile, Sassuolo

Dr. Battista Guidi- UO Pediatria, Ospedale Pavullo nel Frignano, Pavullo nel Frignano

Dr. Giacomo Biasucci- UO di Pediatria e Neonatologia, Ospedale G da

Saliceto, Piacenza

Dr. Belinda Benenati - UO Pediatria, Ospedale G da Saliceto, Piacenza

Dr. Roberta Schiavo- UO Microbiologia e Virologia, Ospedale G da Saliceto, Piacenza

Dr. Giancarlo Piccinini- UO Terapia Intensiva Neonatale, Ospedale Santa Maria delle Croci, Ravenna

Dr. Rita Pulvirenti- UO Pediatria, Ospedale G.B. Morgagni- L. Pierantoni, Forlì Dr. Vittoria Rizzo- UO Terapia Intensiva Neonatale e Pediatrica, Ospedale

Civile M. Bufalini, Cesena

Dr. Gina Ancora- UO Terapia Intensiva Neonatale, Ospedale Infermi, Rimini Dr. Chiara China- UO Terapia Intensiva Neonatale, Ospedale Infermi, Rimini Dr. Irene Papa- UO Terapia Intensiva Neonatale, Ospedale Infermi, Rimini Dr. Laura Viola- UO Pediatria, Ospedale Infermi, Rimini

Dr. Maria Federica Pedna- UO Microbiologia, Laboratorio Unico Ausl della Romagna, Pievesestina

Dr. Jenny Bua- UO Terapia Intensiva Neonatale, IRCCS "Burlo Garofolo", Trieste Dr. Laura Travan- UO Terapia Intensiva Neonatale, IRCCS "Burlo Garofolo",

Trieste

Dr. Marina Busetti- SC Microbiologia e virologia, IRCCS "Burlo Garofolo",

Trieste

Dr. Daniele Santori- SC Pediatria e Neonatologia, Azienda Ospedaliera Santa Maria degli Angeli, Pordenone

Dr. Daniele Merazzi- UO Terapia Intensiva Neonatale, Pediatria e Neonatologia, Ospedale Valduce, Como

Dr. Angela Papa- UO Laboratorio Analisi, Ospedale Valduce, Como

Dr. Ligi Laura- UO Terapia Intensiva Neonatale e Neonatologia, Ospedale S.

Filippo Neri, Roma

Dr. Cinzia Auriti- UO Terapia Intensiva Neonatale, Ospedale Pediatrico

Bambino Gesù, Roma

Dr. Paola Bernaschi- UO Microbiologia, Ospedale Pediatrico Bambino Gesù, Roma Prof. Giovanni Vento- UO Neonatologia, Policlinico Universitario A. Gemelli, Roma Dr. Lucia Giordano- UO Neonatologia, Policlinico Universitario A. Gemelli, Roma

Dr. Teresa Spanu- UO Microbiologia, Policlinico Universitario A. Gemelli, Roma

Dr. Cristina Haass- UO Pediatria e Neonatologia, Ospedale S. Pietro Fatebene Fratelli, Roma

Dr. Maria Carmela Margiotta- UO Microbiologia, Ospedale S. Pietro Fatebene Fratelli, Roma

Dr. Giovanna Nardella- UO Neonatologia, Azienda Ospedaliera Universitaria Ospedali Riuniti, Foggia

Dr. Rosella De Nittis- UO Microbiologia, Azienda Ospedaliera Universitaria Ospedali Riuniti, Foggia

Prof. Nicola Laforgia- UO Terapia Intensiva Neonatale e Neonatologia,

Ospedale Policlinico, Bari

Dr Sabrina Loprieno- UO Terapia Intensiva Neonatale e Neonatologia,

Ospedale Policlinico, Bari

Dr. Latorre Giuseppe- UO Terapia Intensiva Neonatale, Ospedale Generale Regionale "F. Miulli", Acquaviva delle Fonti

Dr. Angela Maria Moramarco- UO Microbiologia, Ospedale Generale Regionale "F. Miulli", Acquaviva delle Fonti

Dr. Chryssoula Tzialla- UO Neonatologia, Patologia Neonatale e Terapia Intensiva Neonatale, Fondazione IRCCS Policlinico "San Matteo", Pavia Dr. Valeria Fasolato- UO Terapia Intensiva Neonatale, Neonatologia e Nido, Ospedale Carlo Poma, Mantova

Dr. Silvia Orlandini- UO Terapia Intensiva Neonatale, Neonatologia e Nido, Ospedale Carlo Poma, Mantova

Dr. Lidia Decembrino - UO Pediatria e Nido, Ospedale Civile, Vigevano Dr. Giulia Del Campo- UO Pediatria e Nido, Ospedale Civile, Vigevano Dr. Angela Maiocchi- UO Microbiologia, Ospedale Civile, Vigevano 
Dr. Armando Cuttano- UO Neonatologia, Azienda Ospedaliero-Universitaria Pisana, Pisa

Dr. Cristina Tuoni- UO Neonatologia, Azienda Ospedaliero-Universitaria Pisana, Pisa

Dr. Simona Barnini- UO Microbiologia, Azienda Ospedaliero-Universitaria Pisana, Pisa

Prof. Virgilio Carnielli- UO Terapia Intensiva Neonatale e Neonatologia, P.O.

"G. Salesi" AOU Ospedali Riuniti, Ancona

Dr. Barbara Perrone- UO Terapia Intensiva Neonatale e Neonatologia, P.O. "G. Salesi" AOU Ospedali Riuniti, Ancona

Dr. Francesca Orecchioni- UO Microbiologia, P.O. "G. Salesi" AOU Ospedali Riuniti, Ancona

Dr. Federica Visintini- SC Patologia Neonatale e Terapia Intensiva Neonatale, Ospedale S. Maria della Misericordia, Udine

Dr. Alessandra Arzese- UO Microbiologia, Ospedale Santa Maria della Misericordia, Udine

\section{Authors' contributions}

$A B$ and $T C$ drafted the initial manuscript, reviewed, revised, and approved the final manuscript as submitted. RC, CV, SA, MS and FF designed the data collection instruments, drafted the initial manuscript, reviewed, revised, and approved the final manuscript as submitted. KLD, PH and SC conceptualized and designed the study, critically reviewed the manuscript, and approved the final manuscript as submitted. All authors approved the final manuscript as submitted and agree to be accountable for all aspects of the work.

\section{Availability of data and materials}

Not applicable.

\section{Ethics approval and consent to participate}

Prot $N^{\circ} 0011051 / 20$ del 20/04/2020.

\section{Consent for publication}

Not applicable.

\section{Competing interests}

The authors declare that they have no competing interests.

Prof Alberto Berardi has received funding from the Institute for Infection and Immunity Paediatric Infectious Diseases Research Group St George's University of London (UK).

The remaining authors declare they have no funding source.

Financial disclosure: Prof. Alberto Berardi has not received fees.

\section{Author details}

${ }^{1}$ Unità Operativa di Terapia Intensiva Neonatale, Dipartimento Integrato Materno-Infantile, Azienda Ospedaliero-Universitaria Policlinico, Via del Pozzo, 71, 41124 Modena, Italy. ${ }^{2}$ Unità Operativa di Microbiologia Clinica, Azienda Ospedaliero- Universitaria Policlinico, Modena, Italy. ${ }^{3}$ Reparto di Antibiotico Resistenza e Patogeni Speciali (AR-PS), Dipartimento di Malattie Infettive, Istituto Superiore di Sanità, Rome, Italy. ${ }^{4}$ Unità Operativa di Microbiologia Clinica, Centro di Riferimento Regionale per le Emergenze Microbiologiche, (CRREM), Policlinico S. Orsola-Malpighi, Università di Bologna, Bologna, Italy. ${ }^{5}$ Unità Operativa di Microbiologia, Azienda Ospedaliero-Universitaria S. Orsola-Malpighi, Bologna, Italy. ${ }^{6}$ Department of Medical and Surgical Sciences for Mother, Child and Adult, University of Modena and Reggio Emilia, Azienda Ospedaliero Universitaria Policlinico, Modena, Italy. ${ }^{7} \mathrm{MRC/}$ UVRI and LSHTM Uganda Research Unit, Entebbe, Uganda. ${ }^{8}$ Department of Clinical Research, LSHTM, London, UK. 'SSt George's Vaccine Institute, Institute of Infection and Immunity, St George's, University of London, London, UK.

${ }^{10}$ Paediatric Infectious Diseases Research Group, St George's University of London, London, UK.

Received: 12 September 2020 Accepted: 19 October 2020 Published online: 28 October 2020

\section{References}

1. Edwards MS, Nizet V, Baker CJ. Group B streptococcal infections. In: Remington and Klein's infectious diseases of the fetus and newborn infant. 8th ed. Philadelphia: Elsevier; 2016. p. 411-56.

2. Berardi A, Cattelani C, Creti R, Berner R, Pietrangiolillo Z, Margarit I, Maione D, Ferrari F. Group B streptococcal infections in the newborn infant and the potential value of maternal vaccination. Expert Rev Anti-Infect Ther. 2015; 13(11):1387-99. https://doi.org/10.1586/14787210.2015.1079126 Epub 2015 Aug 20

3. World Health Organisation. GBS vaccine research and development technical roadmap and WHO preferred product characteristics. Geneva: World Health Organisation; 2016.

4. Centers for Disease Control and Prevention. ABCs Report: Group B Streptococcus, 2017 https://www.cdc.gov/abcs/reports-findings/survreports/ gbs17.html.

5. Davies HG, Carreras-Abad C, Le Doare K, Heath PT. Group B Streptococcus: Trials and Tribulations. Pediatr Infect Dis J. 2019;38(6S Suppl 1):S72-S76. doi: https://doi.org/10.1097/INF.0000000000002328. PMID: 31205250 Review.

6. Ficara M, Pietrella E, Spada C, et al. Changes of intestinal microbiota in early life. J Matern Fetal Neonatal Med. 2018;10:1-8.

7. Carreras-Abad C, Ramkhelawon L, Heath PT, Le Doare K. A vaccine against group B Streptococcus: recent advances. Infect Drug Resist. 2020;13:126372. https://doi.org/10.2147/IDR.S203454 eCollection 2020. PMID: 32425562.

8. Unicef; World Health Organization; The world Bank; United Nations. Levels and Trends in Child Mortality. Report 2019; 2019.

9. Shakib JH, Korgenski K, Sheng X, et al. Tetanus, diphtheria, acellular pertussis vaccine during pregnancy: pregnancy and infant health outcomes. J Pediatr. 2013;163:1422-6.

10. Munoz FM, Ferrieri P. Group B streptococcus vaccination in pregnancy: moving toward a global maternal immunization program. Vaccine. 2013;31: 46-51.

11. Vekemans J, Crofts J, Baker CJ, Goldblatt D, Heath PT, Madhi SA, Le Doare K, Andrews N, Pollard AJ, Saha SK, Schrag SJ, Smith PG, Kaslow DC. The role of immune correlates of protection on the pathway to licensure, policy decision and use of group B Streptococcus vaccines for maternal immunization: considerations from World Health Organization consultations. Vaccine. 2019;37(24):3190-8. https://doi.org/10.1016/j.vaccine.2019.04.039 Epub 2019 Apr 25. PMID: 31031031.

12. Le Doare K, Kampmann B, Vekemans J, Heath PT, Goldblatt D, Nahm MH, Baker C, Edwards MS, Kwatra G, Andrews N, Madhi SA, Ter Meulen AS, Anderson AS, Corsaro B, Fischer P, Gorringe A. Serocorrelates of protection against infant group B streptococcus disease. Lancet Infect Dis. 2019;19(5): e162-71. https://doi.org/10.1016/S1473-3099(18)30659-5 Epub 2019 Jan 22. PMID: 30683467

\section{Publisher's Note}

Springer Nature remains neutral with regard to jurisdictional claims in published maps and institutional affiliations.
Ready to submit your research? Choose BMC and benefit from:
- fast, convenient online submission
- thorough peer review by experienced researchers in your field
- rapid publication on acceptance
- support for research data, including large and complex data types
- gold Open Access which fosters wider collaboration and increased citations
- maximum visibility for your research: over $100 \mathrm{M}$ website views per year
At BMC, research is always in progress.
Learn more biomedcentral.com/submissions 